\title{
Synergistic Interactions in Microbial Biofilms Facilitate the Establishment of Opportunistic Pathogenic Fungi in Household Dishwashers
}

\author{
Jerneja Zupančič ${ }^{1+}$, Prem K. Raghupathi',3t, Kurt Houf ${ }^{3}$, Mette Burmølle'2, \\ Søren J. Sørensen ${ }^{2 *}$ and Nina Gunde-Cimerman ${ }^{1 *}$
}

${ }^{1}$ Department of Biology, Biotechnical Faculty, University of Ljubljana, Ljubljana, Slovenia, ${ }^{2}$ Molecular Microbial Ecology Group, Section of Microbiology, Department of Biology, University of Copenhagen, Copenhagen, Denmark, ${ }^{3}$ Laboratory of Hygiene and Technology, Department of Veterinary Public Health and Food Safety, Faculty of Veterinary Medicine, Ghent University, Ghent, Belgium

OPEN ACCESS

Edited by: Satoshi Tsuneda,

Waseda University, Japan

Reviewed by:

Dong Li,

University of California,

Santa Barbara, United States

Dieter Maurice Tourlousse,

National Institute of Advanced Industrial Science and Technology,

Japan

*Correspondence:

Nina Gunde-Cimerman nina.gunde-cimerman@bf.uni-lj.si

Søren J. Sørensen sjs@bio.ku.dk

†Shared first authorship

Specialty section:

This article was submitted to Microbial Physiology and Metabolism, a section of the journal Frontiers in Microbiology

Received: 07 November 2017 Accepted: 05 January 2018 Published: 30 January 2018

Citation:

Zupančič J, Raghupathi PK, Houf K,

Burmølle M, Sørensen SJ and

Gunde-Cimerman N (2018)

Synergistic Interactions in Microbial Biofilms Facilitate the Establishment of Opportunistic Pathogenic Fung in Household Dishwashers.

Front. Microbiol. 9:21.

doi: 10.3389/fmicb.2018.00021
Biofilms formed on rubber seals in dishwashers harbor diverse microbiota. In this study, we focussed on the microbial composition of bacteria and fungi, isolated from a defined area of one square centimeter of rubber from four domestic dishwashers and assessed their abilities to in vitro multispecies biofilm formation. A total of 80 isolates (64 bacterial and 16 fungal) were analyzed. Multiple combinations of bacterial isolates from each dishwasher were screened for synergistic interactions. 32 out of 140 tested (23\%) four-species bacterial combinations displayed consistent synergism leading to an overall increase in biomass, in all experimental trails. Bacterial isolates from two of the four dishwashers generated a high number of synergistically interacting four-species consortia. Network based correlation analyses also showed higher co-occurrence patterns observed between bacterial members in the same two dishwasher samples, indicating cooperative effects. Furthermore, two synergistic fourspecies bacterial consortia were tested for their abilities to incorporate an opportunistic fungal pathogen, Exophiala dermatitidis and their establishment as biofilms on sterile ethylene propylene diene monomer M-class (EPDM) rubber and polypropylene (PP) surfaces. When the bacterial consortia included $E$. dermatitidis, the overall cell numbers of both bacteria and fungi increased and a substantial increase in biofilm biomass was observed. These results indicate a novel phenomenon of cross kingdom synergy in biofilm formation and these observations could have potential implications for human health.

Keywords: synergism, biofilm formation, EPDM, Exophiala dermatitidis, dishwashers, multispecies biofilm

\section{INTRODUCTION}

Biofilms are defined as highly structured communities of microorganisms that are attached to each other, commonly surface associated and enclosed within a self-produced matrix of extracellular polymeric substance (EPS) (Costerton et al., 1995). The advantages obtained by organisms from producing biofilms include protection from harsh environments, enhanced tolerance to physical and chemical stress, metabolic cooperation and community-coordinated adjustment of gene 
expression. Microorganisms in biofilms adapt their physiology and stress responses and display collective and coordinated behavior (Donlan, 2002; Chmielewski and Frank, 2004; Van Houdt and Michiels, 2010).

Multispecies biofilms are common and often dominant in natural environments (Donlan, 2002; Hall-Stoodley et al., 2004). Resident microorganisms interact with each other in both synergistic and antagonistic manner affecting the biofilm biomass, functionality and tolerance compared to mono-species biofilms (Filoche et al., 2004; Sharma et al., 2005; Burmølle et al., 2006; Moons et al., 2009; Wen et al., 2010; Pathak et al., 2012; Schwering et al., 2013; Lee et al., 2014; Ren et al., 2015; Madsen et al., 2016).

Biofilms are a source of food contamination and food safety related problems (Carpentier and Chassaing, 2004; Srey et al., 2013; Røder et al., 2015). In food production facilities, pathogenic bacteria may benefit from biofilm formation (Klayman et al., 2009) as biofilms can withstand higher temperatures, standard cleaning procedures (Marouani-Gadri et al., 2009) and commonly used disinfectants (Corcoran et al., 2014) thereby, leading to biofilm related outbreaks (Donlan, 2002; de Souza et al., 2015). Most studies focus on the biology and persistence of monocultures of a particular bacterial pathogen in biofilm (Lister and Horswill, 2014; Tolker-Nielsen, 2014), however, there is a growing need to understand the impact of interspecies interactions on the formation and architecture of biofilms (Elias and Banin, 2012; Sheppard and Howell, 2016). Increasing evidence points to the role of fungi in biofilms involved in human diseases (Ramage et al., 2009; Hoarau et al., 2016; Kalan et al., 2016). In mixed bacterial and fungal biofilms, it was reported that bacterial cells gained protection within the matrix and increased its tolerance to antimicrobials and stress (De Brucker et al., 2015; Kong et al., 2016).

Recently, it was discovered that the extreme depauperate ecosystem of household appliances, such as dishwashers, washing machines and coffee machines, harbor selected polyextremotolerant bacteria and fungi (Zalar et al., 2011; Babič et al., 2015; Callewaert et al., 2015; Vilanova et al., 2015; Zupančič et al., 2016; Raghupathi et al., 2018). These microbes resist both high and low $\mathrm{pH}$, temporary increase in temperatures up to $74^{\circ} \mathrm{C}$, desiccation, high organic loads, high concentrations of $\mathrm{NaCl}$ and mechanical stress from water ejectors (Zalar et al., 2011; Zupančič et al., 2016). They are represented by diverse human opportunistic fungi (Zalar et al., 2011;
Döğen et al., 2013; Gümral et al., 2016; Zupančič et al., 2016) and bacteria (Raghupathi et al., 2018).

We have focussed on mixed biofilms in dishwashers since there is a worldwide increase in demand for household appliances (Freedonia, 2016) and opportunistic pathogens detected in these machines could be an emerging threat to human health (Binder et al., 1999; Morens et al., 2004). Despite the ubiquity of microbial communities and the presence of dishwashers in many private households, interspecies interactions among different bacteria and fungi have not been investigated in these systems. The focus of present research was to identify the species composition of bacteria and fungi from the rubber seals of four different dishwashers. The viable bacterial and fungal isolates were identified using a combination of classical and molecular methods. Multiple combinations of different bacterial isolates from each these dishwashers were co-cultured in vitro and their ability to form stable, four-species biofilms was assessed. The synergistic bacterial consortia were tested for their ability to incorporate Exophiala dermatitidis (the most common opportunistic fungal pathogen found in dishwashers) (Zalar et al., 2011; Döğen et al., 2013; Gümral et al., 2016; Zupančič et al., 2016) and their establishment as mixed bacterial-fungal biofilm on different surfaces commonly used in dishwashers were investigated.

\section{MATERIALS AND METHODS}

\section{Cultivation and Identification of Microbial Community}

Microbial biofilms formed on $1 \mathrm{~cm}^{2}$ area of rubber seal from four different dishwashers were sampled in this study (Table 1). The dishwashers varied in age, i.e., years in operation; frequency of use, i.e., the number of times the dishwasher was used per week; and incoming tap water hardness. The water supply connected to these dishwashers (DWs) was characterized based on ion analysis method (Babič et al., 2013). Final concentrations were determined following the method from ISO Standard SIST EN ISO 11885:2009. Biofilm samples were collected with sterile swabs (Invasive sterile EUROTUBO ${ }^{\circledR}$ collection swab). Sampling of microbiota was performed by rubbing a cotton swab moistened with physiological saline over $1 \mathrm{~cm}^{2}$ rubber seal surfaces, immediately after the termination of the washing cycle in these dishwashers. Swab samples were stored in sterile collection tubes at $4^{\circ} \mathrm{C}$ and were processed within a day.

TABLE 1 | Dishwashers sampled for microbial composition in this study.

\begin{tabular}{|c|c|c|c|c|c|}
\hline Dishwasher & Country; city; GPRS coordinates & Age (years in use) & Frequency of use/week & Influent water & NCBI SRR \\
\hline DW1 & Sl; Žalec; $46^{\circ} 15^{\prime} 3.59^{\prime \prime} \mathrm{N} 15^{\circ} 9^{\prime} 50.18^{\prime \prime} \mathrm{E}$ & 3 & 7 & $\mathrm{SH}$ & 3279031 \\
\hline DW2 & SI; Ljubljana; $46^{\circ} 03^{\prime \prime} \mathrm{N} 14^{\circ} 30^{\prime \prime} \mathrm{E}$ & 5 & 3 & $\mathrm{MH}$ & 3335242 \\
\hline DW3 & 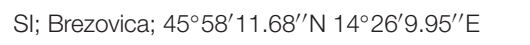 & 7 & 3 & $\mathrm{MH}$ & 3343759 \\
\hline DW4 & SI; Novo Mesto; $45^{\circ} 47^{\prime} 54.88^{\prime \prime} \mathrm{N} 15^{\circ} 10^{\prime} 26.08^{\prime \prime} \mathrm{E}$ & 8 & 7 & MS & 3335236 \\
\hline
\end{tabular}

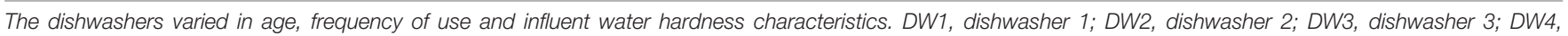

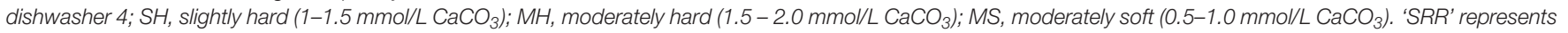
the sequence read archive assigned after deposition of $16 s$ rRNA gene marker-based amplicon reads to NCBI database. 
Viable microbes living in close contact from each of these dishwashers were cultivated by plating methods to obtain individual bacterial and fungal colonies. For each dishwasher sample, $3 \mathrm{ml}$ of sterile physiological saline was added into the collection tube containing swabs and vortexed intensely for $1 \mathrm{~min}$ at maximum speed. Subsequently, for bacterial screening, aliquots of $100 \mu \mathrm{l}$ of the sample were diluted 10-fold and plated on different bacteriological agar media, i.e., nutrient agar (NA), Brain-Heart Infusion agar (BHI), Reasoner's 2A agar (R2A), and Minimal Media agar (M9) (Vogel and Bonner, 1956). All plates were supplemented with cycloheximide (CYC, $50 \mu \mathrm{g} \mathrm{ml}^{-1}$, Sigma) to ensure only bacterial growth. Plates were incubated aerobically at $37^{\circ} \mathrm{C}$ for 2 days (NA and $\mathrm{BHI}$ ) and up to 7 days for M9. In case of R2A, plates were incubated for 7 days at $35^{\circ} \mathrm{C}$. Isolation of fungi was performed by inoculating same aliquots of $100 \mu \mathrm{l}$ of the above diluted suspension on Malt Extract Agar (MEA) (Oxoid, Hampshire, United Kingdom) supplemented with $0.05 \mathrm{~g} / \mathrm{l}$ chloramphenicol, and incubated at 30 and $37^{\circ} \mathrm{C}$ for up to 7 days.

Microbial colonies of various morphotypes (both bacterial and fungal) were restreaked several times on chosen media plates Luria Bertani (LB) for bacteria and MEA for fungi until pure cultures were obtained. The pure cultures were deposited and can be obtained from the Ex Culture Collection, part of the Infrastructural Centre Mycosmo (MRICUL) at the Department of Biology, Biotechnical Faculty, University of Ljubljana, Slovenia.

\section{Identification of Isolates Using Sanger Sequencing}

DNA extraction and molecular identification of fungal isolates from dishwashers was performed as previously described (Zupančič et al., 2016). Briefly, pure fungal cultures were transferred to fresh MEA medium and after 3-7 days of incubation, DNA extractions were performed with methods specific to the type of fungal isolates. For yeasts, DNA extraction was done using PrepMan Ultra Sample Preparation Reagent (Applied Biosystems) according to the manufacturer's instructions. DNA extractions of filamentous fungi and Exophiala strains were done according to Gerrits van den Ende and de Hoog (1999), after mechanical lysis of the mycelium. Fusarium strains were identified using nuclear translation elongation factor 1-alpha (tef) sequences, amplified with the EF1 and EF2 primers (O’Donnell et al., 1998).

Bacterial identification was performed using the extracted genomic DNA from overnight grown pure cultures (LB plates incubated at $37^{\circ} \mathrm{C}$ ) using PrepMan Ultra Sample Preparation Reagent (Applied Biosystems) according to the manufacturer's instructions. PCR amplifications based on 16S rRNA gene with oligonucleotide primers 27F and 1492R targeting bacterial 16S ribosomal gene (Lane, 1991) were applied for bacterial identification. The amplified fragments were Sanger sequenced (Microsynth $\mathrm{AG}$ ) and the 16S rRNA gene sequences were trimmed to approx. $800 \mathrm{bp}$ amplicons and identification was done using Ribosomal Database Project-II (RDP) $)^{1}$ and National

${ }^{1}$ http://rdp.cme.msu.edu
Center for Biotechnology Information (NCBI) BLAST tool searching GenBank. RDP Seqmatch was used against the 16S rRNA database with sequences from isolated bacteria in order to determine the closest known relatives. The sequences were also compared against GenBank non-redundant nucleotide database using NCBI BlastN (Megablast). The isolates were assigned at species level with the Seqmatch score (S-ab) $\geq 0.99$ (99\% similarity) or at genus level with $S$-ab score of $\geq 0.95$ ( $95 \%$ similarity). Sequences were uploaded to the NCBI database and the accession numbers are provided (Table 2).

\section{Growth Media and Conditions}

To determine the optimal growth conditions and to evaluate the biofilm-forming capabilities of microorganisms obtained in this study, we selected 7 bacterial isolates from each of the four dishwashers providing a total of 28 bacterial isolates (Table 2). Selections of isolate were made between different phylogenetically diverse bacterial species in each dishwasher. These isolates were subcultured from frozen glycerol stocks onto LB (Luria-Bertani) agar plates and incubated for $24 \mathrm{~h}$ at $37^{\circ} \mathrm{C}$. A single colony of each bacterial isolate was inoculated into $5 \mathrm{ml}$ LB media tubes, incubated overnight at $37^{\circ} \mathrm{C}$ while shaken at $200 \mathrm{rpm}$.

\section{In Vitro Bacterial Multispecies Biofilm Cultivation}

The seven selected isolates from each dishwasher (Table 2) were screened for biofilm formation as single species and in four-species combinations as described previously (Ren et al., 2015; Røder et al., 2015) with few modifications. Serial 10-fold dilutions of bacterial cultures were performed from overnight grown cultures (in LB media) where $1 \mathrm{ml}$ of the dilutions were inoculated with $29 \mathrm{ml}$ fresh LB media, incubated overnight at $37^{\circ} \mathrm{C}$ and shaking at $200 \mathrm{rpm}$. Cell cultures in exponential phase $\left(\mathrm{OD}_{600}\right.$ between 0.3 and 0.7$)$ were then selected, centrifuged at $8000 \mathrm{rpm}\left(10 \mathrm{~min}, 21^{\circ} \mathrm{C}\right)$, washed with $1 \mathrm{x}$ phosphate buffer saline (PBS) and re-suspended in 10\% w/v LB media (reduced). The optical density $\mathrm{OD}_{600}$ of each bacterial culture was then adjusted to 0.15 in the reduced LB media. Biofilm cultivation assay was performed using 96-well microtiter plates (NUNC, Roskilde, Denmark) and peg lids (NUNC-TSP lid system, Roskilde, Denmark) placed on top of the plates, also referred to as the Calgary method (Ceri et al., 1999). A total of $150 \mu \mathrm{l}$ as monospecies or four mixed species ( $37.5 \mu \mathrm{l}$ of each species) cultures were added to each well. Each plate contained the representative mono-species cultures. $150 \mu \mathrm{l}$ 10\% LB served as blank. Plates were incubated at $25^{\circ} \mathrm{C}$ for $24 \mathrm{~h}$.

\section{Network Analysis Data}

While competing for same resources, bacteria present in the same environment potentially co-occur or exclude each other (Roggenbuck et al., 2014). This relationship was characterized by generating the Spearman co-occurrence network (Barberán et al., 2012). The four selected dishwasher in this study, sequenced using Illumina MiSeq platform and taxonomic classifications of the $16 \mathrm{~S}$ rRNA gene sequences 
TABLE 2 | List of selected bacterial isolates used in biofilm cultivation experiments.

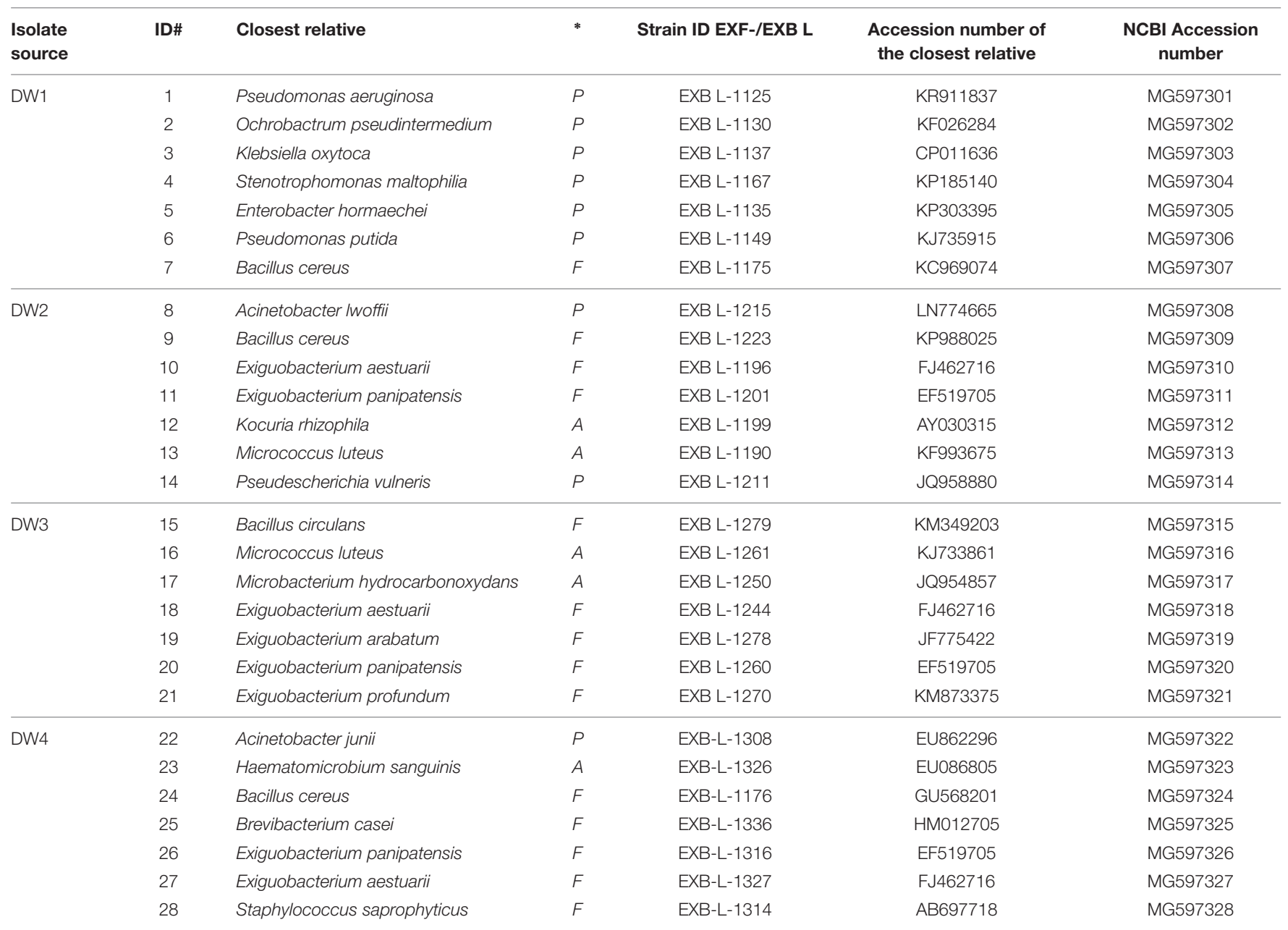

DW1, dishwasher 1; DW2, dishwasher 2; DW3, dishwasher 3; DW4, dishwasher 4; *, Phyla; P, Proteobacteria, F, Firmicutes, A, Actinobacteria. Strain ID represents the isolate identification after deposition (as 'EXF' for fungal and 'EXB-L' for bacterial isolates) at the Microbial Culture Collection EX (MRICUL EX).

based on RDP classifier, were described previously (Raghupathi et al., 2018). Sequence raw reads (SRR) (Table 1) from these dishwashers were made available to NCBI Sequence Read Archive (SRA) under the Bioproject ID: PRJNA315977. The network and predicted interactions were generated on the basis of relative counts of different bacterial genera that had more than 50 sequence observations and represented in $50 \%$ of the samples $(n>2, N=4)$. We present correlation data for log transformed counts using CoNet 1.0b6 plugin in Cytoscape 3.2.1. The correlations were made on the basis of in-built non-parametric Spearman correlation coefficient with a minimal cut-off threshold of $r \geq|0.85|$ ( $p<<0.01$, Bonferroni corrected).

\section{In Vitro Cultivation of Bacterial-Fungal Biofilms}

The bacterial isolates from DW4 were prepared as mentioned above. The fungal strain E. dermatitidis genotype A (EXF-9777), also isolated from DW4 (Table 2), was subcultured from frozen glycerol stocks onto MEA, supplemented with $0.05 \mathrm{~g} / \mathrm{l}$ chloramphenicol and incubated $3-5$ days at $37^{\circ} \mathrm{C}$. A single colony of the black yeast was then inoculated into $5 \mathrm{ml} 10 \% \mathrm{LB}$ media tubes and incubated at $37^{\circ} \mathrm{C}$ while shaken at $200 \mathrm{rpm}$ until an $\mathrm{OD}_{600}$ of approximately 0.7 was reached. Then, with the aim to work with a uniform culture media which will provide a common niche for both bacteria and fungi, LB media was replaced with $10 \% \mathrm{LB}$ and $\mathrm{OD}_{600}$ adjusted to 0.15 . A total of $150 \mu \mathrm{l}$ as mono-species (bacteria/fungi) cultures or $30 \mu \mathrm{l}$ for each species in five mixed species (four bacteria and E. dermatitidis) combinations were added to each well. Also, each plate contained the representative $75 \mu \mathrm{l}$ of mono-species bacterial cultures together with $75 \mu \mathrm{l}$ fungal cultures. Plates were incubated at $25^{\circ} \mathrm{C}$ for 24,48 , and 96 h. $150 \mu \mathrm{l}$ 10\% LB served as blank.

\section{Biofilm Quantification and Screening for Synergistic Interactions}

Mixed species and monospecies biofilm cultivation in a 96-well Calgary Biofilm Device (CBD) and its quantification using 1\% $\mathrm{w} / \mathrm{v}$ crystal violet were performed as described previously (Ren et al., 2015; Røder et al., 2015). We classified synergy, as and when the measured absorbance from the $\mathrm{CBD}$ assay of the multispecies 
biofilm (MSB) being greater than that of the best single strain (BSS) biofilm producer present in the relevant combination when taking standard errors into account, i.e., (Abs $590 \mathrm{MSB}-$ Standard error $)>\left(\right.$ Abs $_{590}$ BSS + Standard error $)=$ Synergy, while $\left(\mathrm{Abs}_{590} \mathrm{MSB}+\right.$ Standard error $)<\left(\mathrm{Abs}_{590} \mathrm{BSS}-\right.$ Standard error) = No synergy (Ren et al., 2015). In case of bacterial-fungal biofilms, synergy was when the absorbance of multispecies bacterial-fungal biofilm was greater than that of the best single strain biofilm producer present together with the fungi (BSS) in the relevant combination when taking standard errors into account. Fold change $\left(F_{d}\right)$ is represented as ratio of the biofilm biomass of multispecies consortia with/without fungi to its best biofilm producer with/without fungi within the respective consortia, i.e., Fold change $=\mathrm{Abs}_{590} \mathrm{MSB}-$ Standard error/Abs 590 (BSS + Standard error). Hence, consortia with an $F_{d}>1$ are designated as synergistic. The above cultivation and quantification of biofilm was performed with three technical replicates and the assay was performed at three different times.

\section{In Vitro Establishment of Multispecies Biofilm on Dishwasher Rubber and Plastic Material and Its Quantification}

Two four-species bacterial consortia from DW4 that showed an overall increase in biofilm formation in all trials, were tested for the incorporation of $E$. dermatitidis using a 24 well plate; as this fungus was found to be present on DW4 rubber seal. Enumeration of fungal and bacterial cells from the biofilm formed on wells was done using fluorescent associated cell sorting system BD FACS Calibur (BD Biosciences). The biofilm on the bottom of the plates were washed gently and the attached cells were scrapped-off, homogenized in $500 \mu \mathrm{l} 1 \mathrm{X}$ PBS and transferred into micro-centrifuge tubes. The fungal cells were selectively stained using Calcofluor White Stain (Sigma-Aldrich) to differentiate from bacterial cells.

Further, the biofilm formation on three different types of elastomer; EPDM [ethylene propylene diene monomer (M-class)] referred to as 17, 18, 19 and three different types of polypropylene (PP) $\left(\mathrm{C}_{3} \mathrm{H}_{6}\right)_{n}$ referred to as $1,2,3$; used in dishwasher industry were tested. The elastomer and plastic material were cut into slices of $1 \mathrm{~cm}^{2}$ size (with active surface $2 \mathrm{~cm} \times 1 \mathrm{~cm}$ ) and sterilized by autoclaving at $121^{\circ} \mathrm{C}$ for $15 \mathrm{~min}$. Bacterial and fungal cultures were prepared as described above. 24-well cell culture plates (TPP ${ }^{\circledR}$ cat. no. 92024, Sigma-Aldrich, United States) were used to cultivate the biofilms on artificial materials of EPDM and PP. A total of $1250 \mu \mathrm{l}$ for monospecies bacterial or fungal cultures or four mixed species $(312,5 \mu \mathrm{l}$ of each bacterial culture), or five mixed species $(250 \mu \mathrm{l}$ of each bacteria and fungi cultures) combinations were added to each well. The same volume of $10 \% \mathrm{LB}$ medium was added as blank. After inoculation, sterile elastomer or plastic parts were aseptically added into the plates. The plates were incubated at $25^{\circ} \mathrm{C}$ for 24,48 , and $120 \mathrm{~h}$. The biofilm assays were performed three times on different days with three technical replicates each time.

The crystal violet method was applied to quantify biofilms formed on EPDM/PP (Ren et al., 2015; Røder et al., 2015) as follows. Briefly, after incubation, in order to wash off loosely attached cells and planktonic fractions, the EPDM/PP substrates were transferred using sterile forceps successively to three 24-well microtiter plates containing $1200 \mu \mathrm{l}$ of $1 \mathrm{X}$ PBS buffer per well, followed by staining of the biofilms formed on the EPDM/PP with $1250 \mu \mathrm{l}$ of an aqueous $1 \%(\mathrm{w} / \mathrm{v}$ ) CV solution. After $20 \mathrm{~min}$, the EPDM/PP substrate was rinsed three times with $1 \mathrm{X}$ PBS and de-stained in $1250 \mu \mathrm{l} 96 \%$ ethanol in each well of a new plate. After $20 \mathrm{~min}$, the absorbance was measured as described above.

\section{RESULTS}

\section{Variation in Total Cultivation Community Structure across Four Different Dishwashers}

Among the dishwashers that were screened for viable microbial population within $1 \mathrm{~cm}^{2}$ isolation area from four DW, a total of 80 isolates (64 bacterial and 16 fungal) were obtained (Supplementary Table S1). Isolates from DW1 contained seven different fungal species and 20 different bacterial species. The fungal isolates belonged to four different classes viz. Saccharomycetes, Chaetothyriomycetes, Sordariomycetes, and Urediniomycetes. Majority of the isolated bacterial species belonged to Proteobacteria; and others belonged to four different bacterial phyla. DW2 had 3 fungal species and 18 different bacterial species belonging to 3 different bacterial phyla. Ten Gram-positive isolates belonging to two bacterial phyla, Firmicutes and Actinobacteria and no fungal isolates were obtained from DW3. Majority of these bacterial isolates belonged to the genus Exiguobacterium. Isolates from DW4 contained three different fungal species belonging to 3 fungal classes and 16 different bacterial species. The 16 isolates belonged to 4 different bacterial phyla. Bacterial isolates from DW3 and DW2 were represented by two or three families (DW3: Microbacteriaceae and Bacillaceae; DW2:-Enterobacteriaceae, Micrococcaceae, and Moraxellaceae) respectively. Bacterial isolates from DW1 and DW4 were represented by five families (DW1: Pseudomonadaceae, Brucellaceae, Enterobacteriaceae, Xanthomonadaceae, and Bacillaceae; DW4: Moraxellaceae, Bacillaceae, Staphylococcaceae, Brevibacteriaceae, and Micrococcaceae). DW2 and DW4 contained the black yeast $E$. dermatitidis, represented by two different genotypes, of which, the clinically relevant genotype A was present in both DWs. Previous results showed the most abundant microbial taxa in these four DW samples identified by 16S rRNA and ITS gene marker based amplicon sequencing (Raghupathi et al., 2018). Most abundant bacterial taxa belonged to genera like Exiguobacterium, Gordonia, Nesterenkonia, Ochrobactrum, Chryseobacterium, Stenotrophomonas, Pseudomona, and Acinetobacter. Most abundant fungal taxa in these four DW samples were represented by genera Candida, Cryptococcus, Rhodotorula, and Exophiala (Raghupathi et al., 2018; Supplementary Figure S1).

Bacteria classified as opportunistic pathogens like Pseudomonas aeruginosa, Ochrobactrum pseudintermedium, 


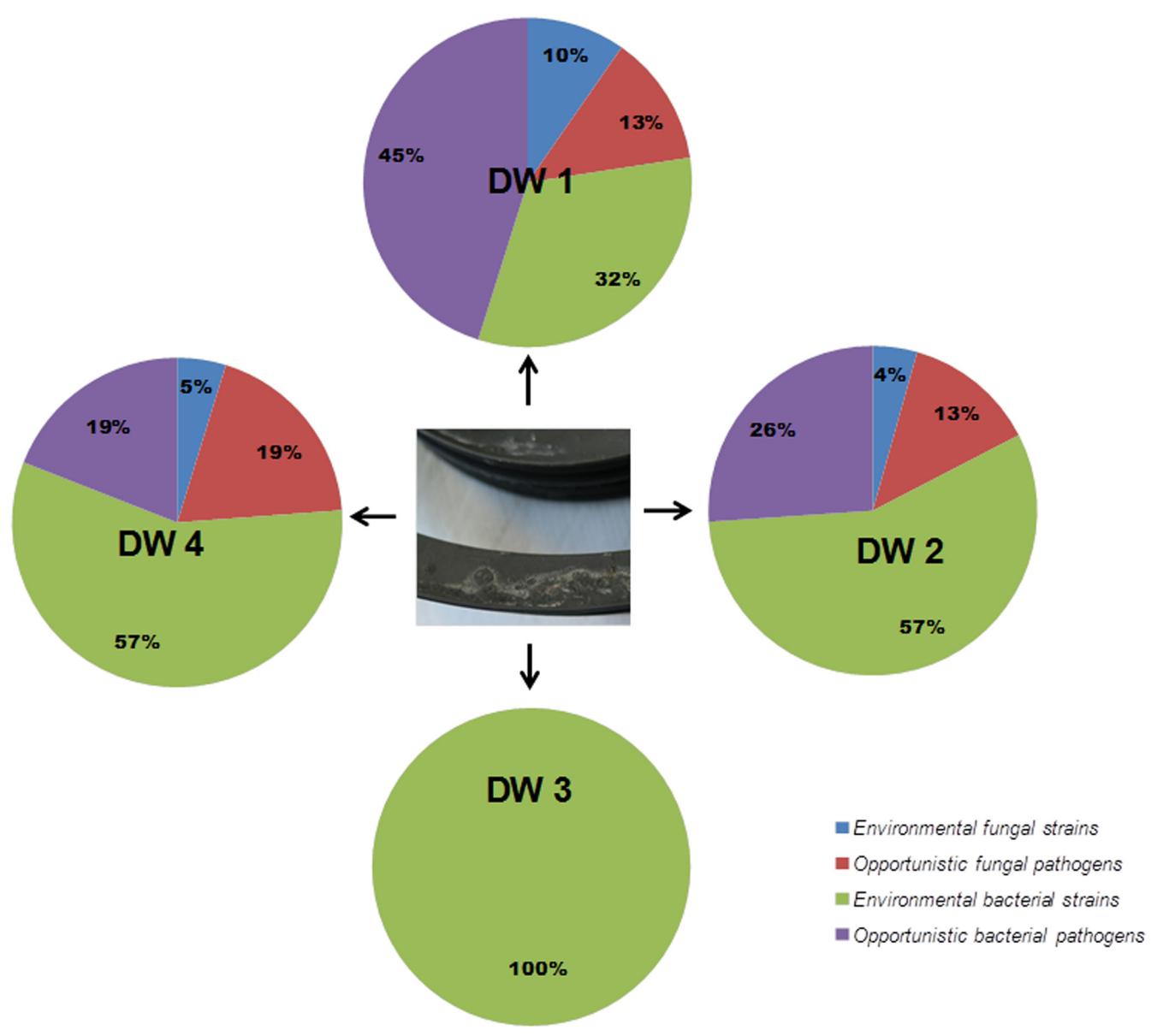

FIGURE 1 | Distribution of microbial population isolated from the rubber seals of 4 dishwashers (DWs). After isolation and identification of both bacteria and fungi, isolates were classified as environmental or opportunistic pathogenic strains based on the taxonomic literature (de Hoog et al., 2014; BMSAB, 2017) in each dishwasher; DW1, dishwasher 1; DW2, dishwasher 2; DW3, dishwasher 3; DW4, dishwasher 4.

Klebsiella oxytoca, and Acinetobacter junii and opportunistic fungal pathogens like E. dermatitidis, Candida parapsilosis, Rhodotorula mucilaginosa, and Fusarium oxysporum species complex (FOSC) were isolated from these dishwashers. Bacterial and fungal isolates from DW1, 2, and 4 were represented by various opportunistic pathogens whereas; the isolates from DW3 were represented by non-pathogenic "environmental" strains (Figure 1). These classifications were made based on known fungal and bacterial taxonomic literatures [de Hoog et al., 2014; Whitman WB, 11th ed. Bergey's Manual of Systematics of Archaea and Bacteria (BMSAB, 2017)].

\section{Multi-Species Interactions Enhance Biofilm Biomass}

Screening for biofilm formation revealed that DW1 and DW4 had higher percentage of four-species consortia with $f_{d}>1$, thus considered to be synergistic in biofilm formation, compared to DW2 and DW3 (Figure 2). Overall 35 four-species combinations were tested per each DW, 140 combinations in total per experiment. Results showed that DW1, DW2, and DW4 had 9, 2, and 21 stable four-species combinations, respectively, [consistently synergistic (fold-change, $f_{d}>1$ )] in all three trials. DW3 had no four-species combinations interacting synergistically across all trials. The absorbance measurements of single and four-species combinations and their corresponding fold-change $\left(f_{d}\right)$ calculated across the three biological trails are shown (Supplementary Table S2).

The four-species consortia were analyzed to identify the different species contributing as key biofilm producers when present within the given consortia. Therefore, the isolates that contributed more frequently to synergy in each four-species combination were obtained. The analysis performed across three trials gave a maximum count of 60 combinations per isolate (Figure 3). In DW1, four-species combinations containing $P$. aeruginosa and Enterobacter hormaechei were more likely to interact synergistically. In DW4, Acinetobacter junii was the most frequent isolate contributing to synergistic interactions. In DW2 and DW3, the frequency of each isolate to engage in a synergistic four-species biofilm varied among different bacterial members. Escherichia vulneris and Exiguobacterium aestuarii in different four-species combinations were more likely to interact synergistically in DW2 and DW3, respectively. 


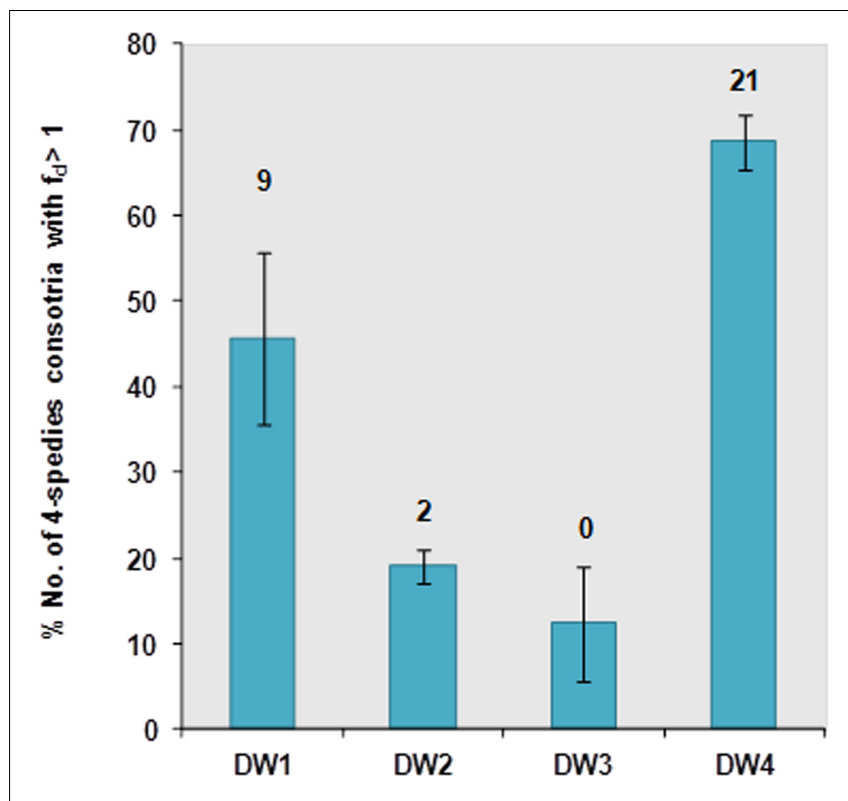

FIGURE 2 | Percentage of synergistic $\left(f_{d}\right.$-value $\left.>1\right)$ four-species bacterial combinations (total; $N=35$ ) from DW1-4 based on CV quantification after $24 \mathrm{~h}$ incubation at $25^{\circ} \mathrm{C}$ in $10 \% \mathrm{LB}$ media. The number above each column bar indicates the total number of four species consortia having $f_{d}$-value $>1$ in all replicates and trials. The experiment was performed at three different times with three technical replicates each time. The error bars denote the percentage mean \pm standard error (SE) from three biological trails.

\section{Potential Interactions between Different Bacterial Taxa Using a Network Based Approach}

Bacterial diversity based on $16 \mathrm{~S}$ rRNA gene sequencing of these four DW biofilm communities was revealed in a previous study (Raghupathi et al., 2018). Significant pairwise interactions $(p<0.01)$ between different bacterial genera from these four DW samples were analyzed. The type of interaction, i.e., positive correlation hypothetically indicates symbiosis, mutualism or commensalism and negative correlation hypothetically indicates mutual exclusions, competition or parasitism (Roggenbuck et al., 2014). It was found that in DW1 and DW4, the numbers of positive correlations were higher than in DW2 and DW3 (Figure 4). The interaction networks within different bacterial genera identified in this study are presented (Supplementary Figure S2). The genera Pseudomonas and Acinetobacter had highest numbers of positive correlations suggesting a potential to co-exist with other bacterial genera.

\section{Bacterial-Fungal Biofilm Development}

Exophiala dermatitidis is known for its dominant presence in household DWs (Zalar et al., 2011; Zupančič et al., 2016). Therefore, its establishment within bacterial biofilms was investigated. Different four-species bacterial consortia from DW4 were tested for their ability to incorporate E. dermatitidis (see Supplementary Table S3). We found that two fourspecies bacterial consortia increased in its overall biofilm production when E. dermatitidis was included. One bacterial consortium (Consortium 1) was composed of Acinetobacter junii (EXB-L-1308), Haematomicrobium sanguinis (EXB-L-1326), Bacillus cereus (EXB-L-1176) and Exiguobacterium aestuarii (EXB-L-1327). The other bacterial consortium (Consortium2) was composed of Acinetobacter junii (EXB-L-1308), Bacillus cereus (EXB-L-1176), Brevibacterium casei (EXB-L-1336), and Exiguobacterium aestuarii (EXB-L-1327). It should be noted that the bacterial consortium 1 when present alone increased in cell numbers over time, however, the bacterial cell numbers reduced overtime in Consortium 1 in the presence of fungal cells. Consortium 2 showed no change in bacterial numbers and fungal numbers increased overtime. These results indicate a shift in population dynamics that could be observed due to resource competition and complex interactions between different microbial species. Interestingly, E. dermatitidis did not form biofilm when grown as fungal monocultures as it did not attach well to the surface of the Calgary biofilm device (CBD) indicated by its low cell numbers. However, when E. dermatitidis was introduced to multispecies bacterial biofilm, the cell numbers increased leading to the formation of the trans-kingdom biofilm (Figure 5).

\section{Industrial Implications}

Synthetic surfaces in many machines and equipment, including household appliances and medical utensils, may become established with microbial biofilm overtime. This could contribute to risks associated with cross-contamination. As an applied aspect of this study, we wanted to assess the establishment and colonization of bacterial-fungal biofilms on different elastomer (EPDM) and polypropylene (PP) surfaces using bacterial Consortium 1 together with $E$. dermatitidis. This multispecies bacterial-fungal biofilm was best formed on elastomer 18, which constitute as the actual rubber material currently used in the industry for rubber seals. Biofilms were less successfully established on elastomer types 17 and 19 (Figure 6A). E. dermatitidis grown as a mono-species fungal biofilm also showed an increased attachment to elastomer 18 compared to elastomers 17 and 19 (Figure 6A). Thus, elastomer 18 represents a preferred surface for microbial biofilm formation. However, based on the absorbance measurements from microbial biomass formed on different PP surfaces; our observation point to PP surfaces providing an even better surface for microbial attachment (Figure 6B) than elastomers. Similar results were observed on bacterial-fungal biofilms using bacterial isolates in Consortia 2 (Supplementary Figure S3).

\section{DISCUSSION}

Survival of microorganisms in extreme environments is often associated with formation of complex biofilms attached on a suitable surface (Davey and O'toole, 2000). In domestic environments, biofilms were examined in tap water supply systems (Mullis and Falkinham, 2013; Burkowska-But et al., 2015; Lührig et al., 2015; Babič et al., 2016; Iakhiaeva et al., 2016; Ling et al., 2016) and in wet niches such as shower heads (Abe et al., 2016). In this study, we focussed 


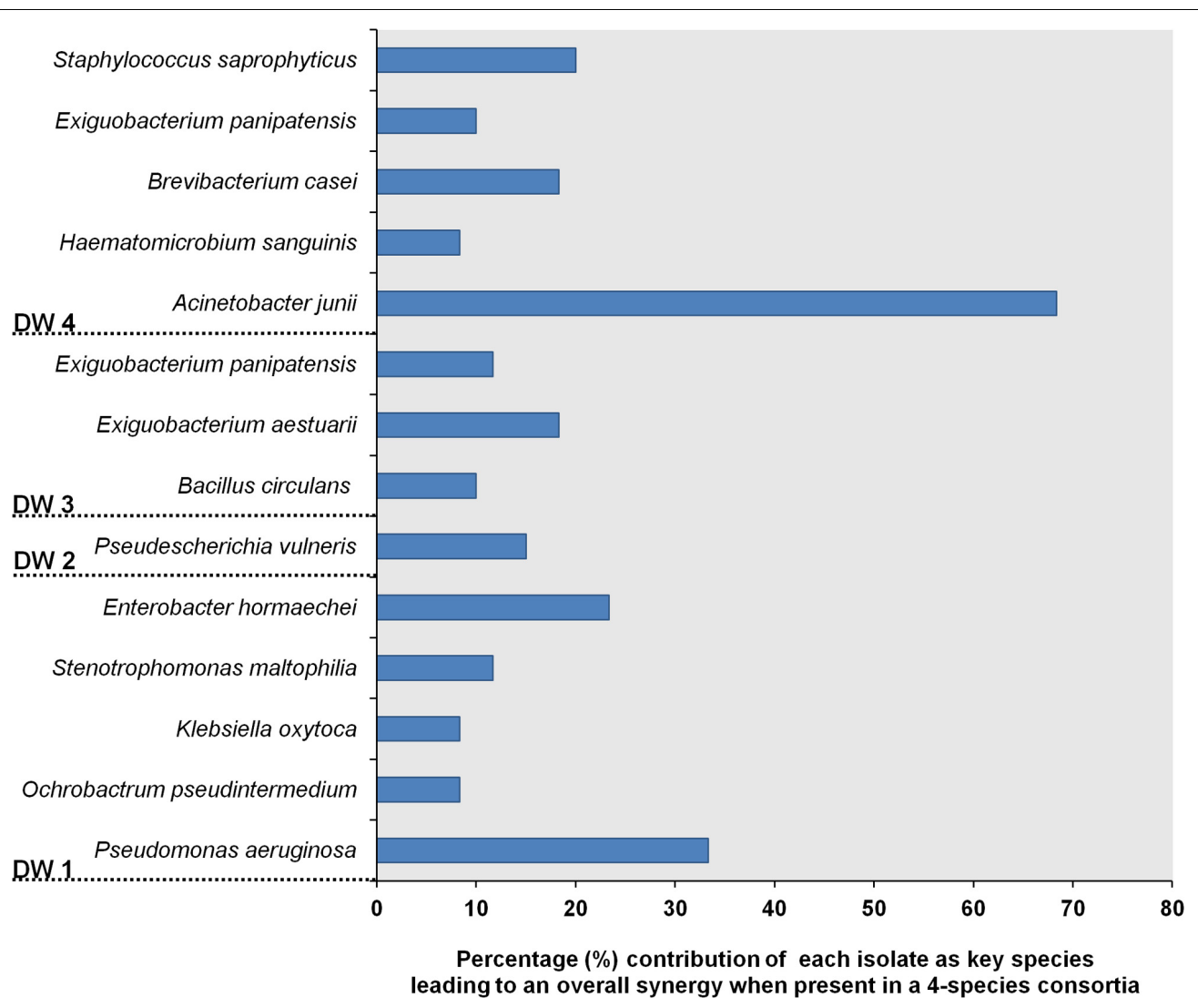

FIGURE 3 | Isolates from dishwashers that were assessed as key species contributing to biofilm synergy when present in a four-species combination. The number of times an isolate contributing to synergy within a four-species consortium were summarized from three trials. Each isolate participated in 20 four species combinations/trial, thus $N=60$ observations.

on the isolation of microorganisms from biofilms formed on rubber seals of four dishwashers (DWs) and used these isolates to determine their biofilm forming abilities in vitro. Bacterial communities that colonized the rubber seals of DWs comprised a wide variety of environmental bacterial species together with a number of species represented as opportunistic pathogens.

The composition of the microbial communities differed considerably among the four DWs. Microbial species obtained from these samples were well represented based on their abundance levels at their genus level (Raghupathi et al., 2018). These results show that most abundant microbial representatives identified by sequencing approach, remained viable in these extreme systems. The dominant bacterial genus, Exiguobacterium was isolated in three out of four DWs. Different species of this genus were known for their ability to proliferate in extreme natural environments like hot, alkaline and marine environments (Vishnivetskaya et al., 2009). Another highly represented bacterial genus was Bacillus. Bacillus is ubiquitous in domestic environments (Gorny et al., 1999; Park et al., 2006) and is widely used in industry as a microbial indicator for cleaning procedures during washing cycles (Ståhl Wernersson et al., 2004; Lee et al., 2007; Nicolella et al., 2011). The diversity of fungi isolated from DWs was in accordance with previous studies (Zalar et al.,
2011; Döğen et al., 2013; Gümral et al., 2016; Zupančič et al., 2016). Black yeasts, E. dermatitidis and E. phaeomuriformis were represented in most dishwashers; followed by white yeasts, Candida parapsilosis and red yeasts, Rhodotorula mucilaginosa. These four fungal species were classified as opportunistic human pathogens (Hiruma et al., 1993; Lunardi et al., 2006; De Almeida et al., 2008; Sudhadham et al., 2008; Trofa et al., 2008; Russo et al., 2010; Kondori et al., 2011; Silva et al., 2012) and with their presence in household DWs, they could represent a potential source for indoor infections (Zupančič et al., 2016).

Bacterial interactions play a major role in shaping and maintaining the diversity within bacterial communities (HilleRisLambers et al., 2012) and also influence the balance between cooperating and competing phenotypes (Nadell et al., 2016). Studies have elucidated the coexistence patterns among microbial groups from a variety of ecosystems using microbial correlation networks (Eiler et al., 2012; Kittelmann et al., 2013; Zhalnina et al., 2013). However, little is known on whether these coexistence patterns reflect the actual biogenic relationships and interactions in situ. In this study, we analyzed the co-occurrence patterns between the different bacterial taxa in the four DW samples. Positive and negative correlations of bacterial taxa were accounted to the genus level. DW1 and DW4 had higher number of positive correlations compared to DW2 and DW3. 


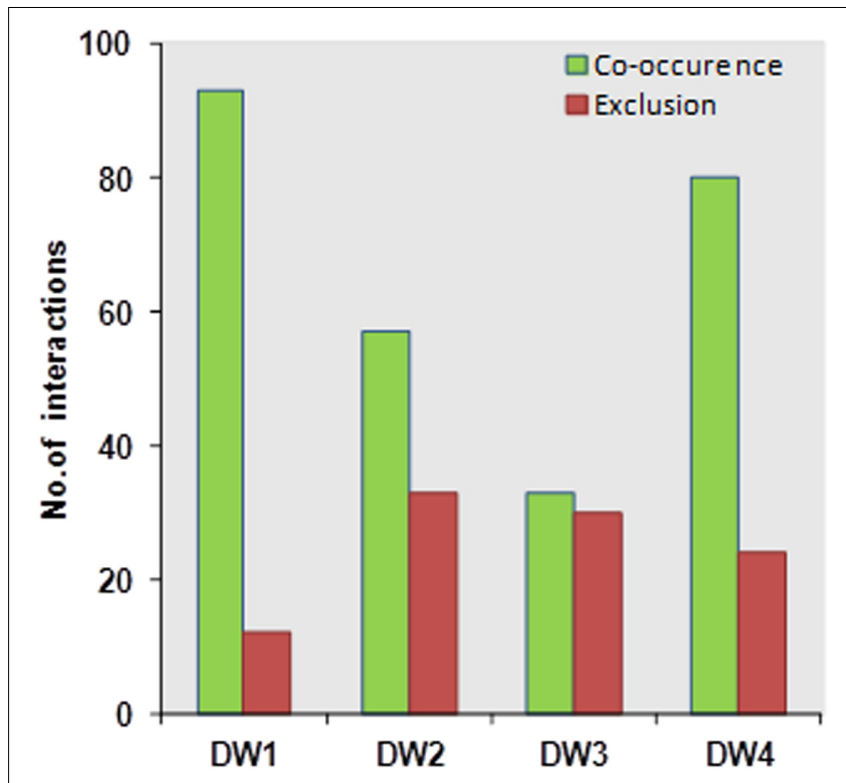

FIGURE 4 | Network based analysis showing the number of co-occurrences and mutual exclusion interactions among bacterial genera identified in the four dishwasher systems generated based on Spearman correlation analysis.

Also, when screened for synergistic multispecies biofilm, it was found that DW1 and DW4 had higher numbers of four-species combinations interacting synergistically leading to an overall increase in biomass.

Biofilm levels of the four-species consortia when further examined and compared to the levels of biofilm production of each isolate under monospecies conditions, it was revealed that $P$. aeruginosa and $A$. junii, isolated from DW1 and DW4, respectively, were found to contribute as best biofilm producers that included poor or non-biofilm producing isolates, increasing the overall biofilm formation within the included consortia. Likewise, co-association networks revealed that the genera Pseudomonas and Acinetobacter had higher number of positive correlations suggesting a potential to cooperate with other bacterial genera. These observations could support our previous evidence where DW1 and DW4 had higher percentage of synergistically interacting four-species biofilm. Likewise, the co-association networks revealed that the genera Exiguobacterium and Micrococcus had higher numbers of negative correlations signaling competition or exclusion to other bacteria. In DW2 and DW3, most combinations included isolates belonging to the genera Exiguobacterium and Micrococcus and the observed number of synergistic four-species consortia were much lower than what was seen in DW1 and DW4. Interestingly, these findings demonstrate an observed trend between the correlation detection technique and in vitro multispecies biofilm assessments, where coexistence of bacterial members within these ecological systems could contribute to multispecies biofilm formation.

Synergy impacts bacterial composition in multispecies biofilms and their overall biomass (Burmølle et al., 2014).

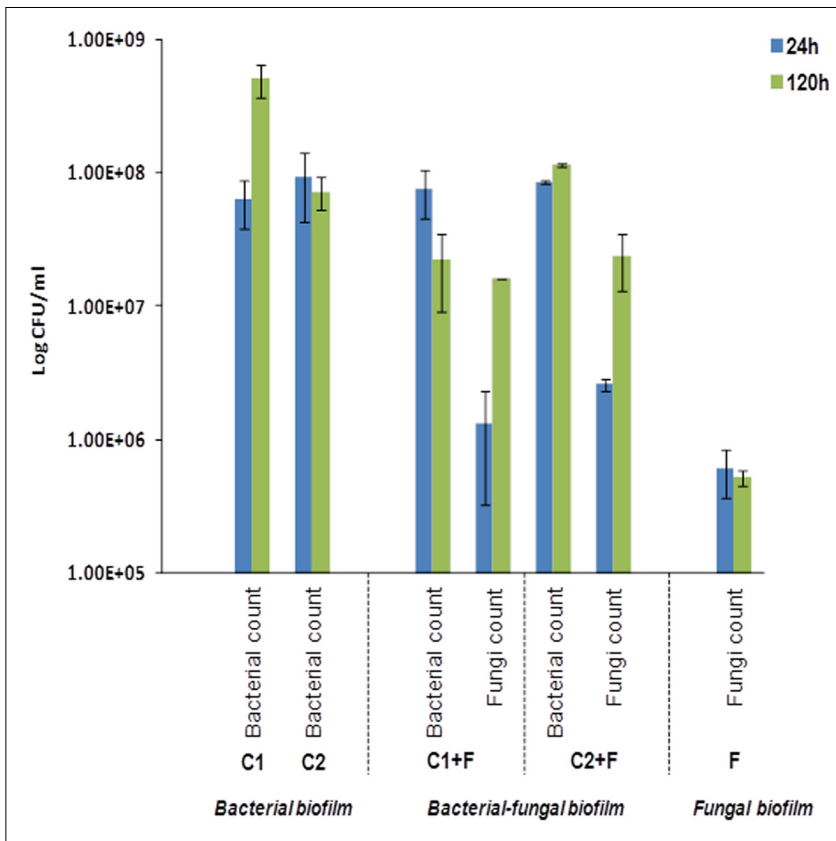

FIGURE 5 | Establishment of fungal cells into bacterial consortia. $\log _{10}$ CFU counts obtained after 24 and $120 \mathrm{~h}$ of incubation at $25^{\circ} \mathrm{C}$ harvested from biofilms formed on the wells using flow cytometry. Consortium $\mathrm{C} 1$ were composed of $A$. junii, $B$. cereus, $H$. sanguinis, and $E$. aestuarii species and consortium C2 were composed of A. junii, B. cereus, B. casei, and E. aestuarii species. C1 and C2 denote the total CFU counts from biofilm formed by the two four-species bacterial consortia with no fungal addition and not of individual isolates within the consortia. ' $\mathrm{C} 1+\mathrm{F}$ ' and ' $\mathrm{C} 2+\mathrm{F}$ ' denote the counts of total bacterial and $E$. dermatitidis cells when these consortia were co-cultured with the fungi $E$. dermatitidis. 'F' denotes the total cell counts of E. dermatitidis when present to form monospecies fungal biofilm. The error bars denote the mean cell counts $\pm S E$ from three biological trials.

Such multispecies biofilms are tolerant against antimicrobials compared to their monospecies equivalents (Schwering et al., 2013; Lee et al., 2014). We have characterized the interactions within different bacterial species and how they impact each other during biofilm development, both under mono and mixed species cultures. Later, the ability of selected mixed bacterial consortia to incorporate the polyextremophile E. dermatitidis, (Zalar et al., 2011; Poyntner et al., 2016) the prevalent fungal species in DW systems, was assessed. Fungi and bacteria play important roles in promoting the survival of their interacting partners (Frey-Klett et al., 2011). Such complex biofilms can be beneficial to all microbial partners, but can be detrimental to the human host (Minerdi et al., 2008; Ghannoum, 2016; Kalan et al., 2016). Our results show that when bacterial consortia were supplemented with $E$. dermatitidis, the biomass production and the numbers of bacteria were stimulated together with the growth of fungal partner in the mixed biofilm. The observations that the bacterial community of DWs facilitating the growth of an opportunistic pathogenic fungus and mixed bacterial-fungal biofilm established on commonly used industrial surfaces (EPDM 18 and PP) complementing their persistence and growth; represent significant findings with scientific and applied 


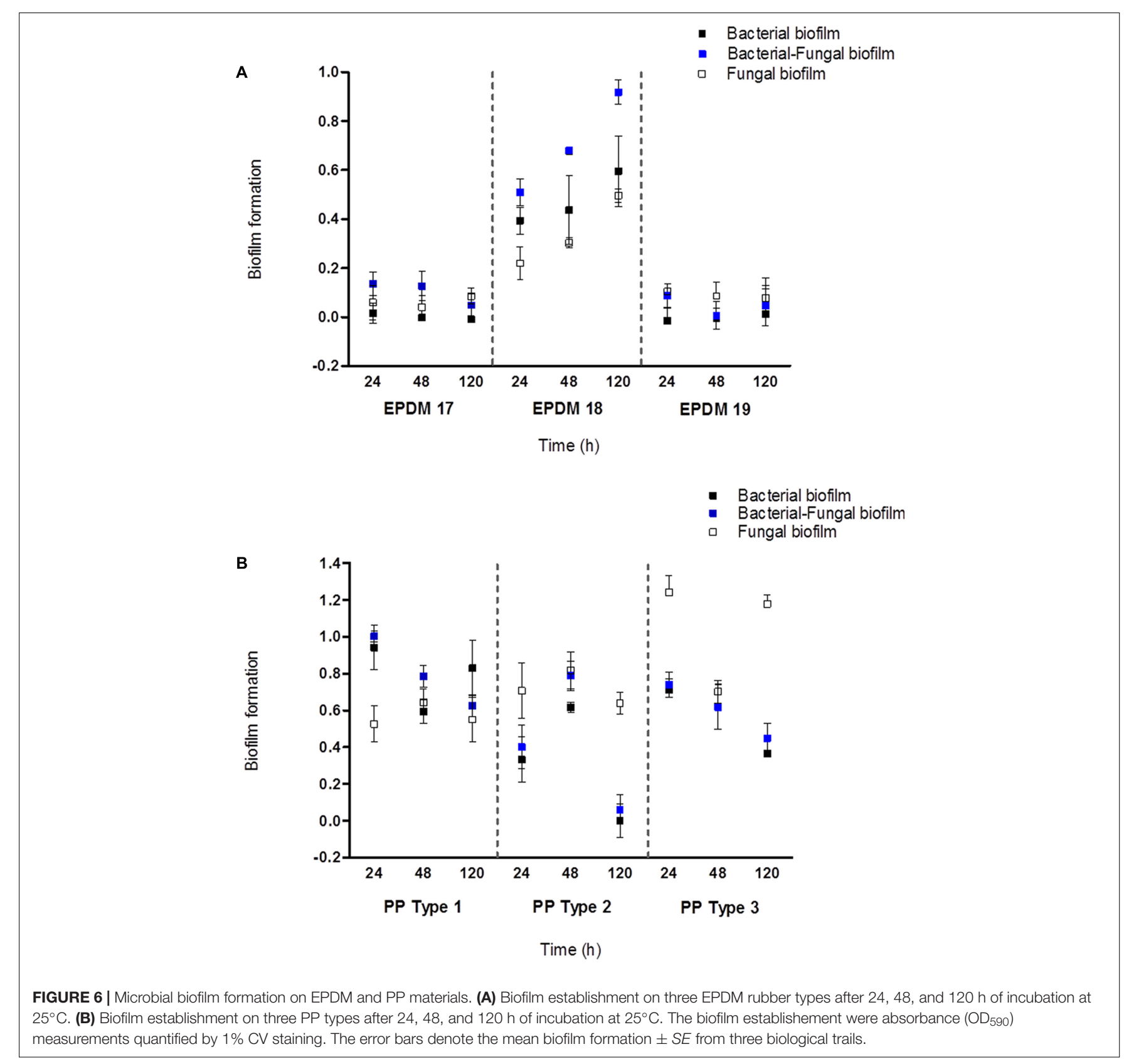

implications. Though these observations are similar to the results obtained in other studies investigating mixed species biofilms like Candida albicans, an opportunistic pathogenic fungi (Seneviratne et al., 2007; Harriott and Noverr, 2011; Pammi et al., 2013), it should be noted that the studies were made using one fungi and single bacteria in co-cultures; whereas, in this study, we present the establishment of an opportunistic black yeast pathogen into mixed bacterial consortium comprising of four species. Further, the formation of bacterial and fungal biofilms on dishwasher related environments emphasize the importance of interactions played between different microbial species and their change in population dynamics across kingdoms during biofilm development.
In summary, our main findings include the existence of synergistic interactions observed during biofilm formation between bacteria isolated from different DWs where, A. junii and $P$. aeruginosa were recognized as the best biofilm producers and important contributors to synergy. This finding corresponds with network based co-occurrence analysis where these two bacterial genera in dishwasher systems, account to most positive correlations observed. In addition, mixed bacterial biofilms could incorporate the opportunistic yeast pathogen, E. dermatitidis and facilitate its establishment on rubber seals and other surfaces. The enhancement of trans-kingdom biofilm formation on rubber surface used in DWs suggests that microbes surviving these environments have been selected by their ability to 
engage in synergistic biofilm formation. With our study, we have shown that our experimental model has the capacity to reveal new and unique features of these complex and dynamic microbial communities. Additionally, our observations and methodology could have important implications for future design and maintenance of house-hold and medical appliances, as these systems could present as a source of domestic crosscontamination and human infections.

\section{ETHICS STATEMENT}

In this study, field sampling was performed, and to our knowledge, no endangered or protected species were involved. All of the samples studied here were obtained from the discussed sampling areas, for which permission was obtained from the owners.

\section{AUTHOR CONTRIBUTIONS}

SS, NG-C, and MB designed the study. JZ and PR performed the experiments and analyzed the data. JZ, PR, KH, NG-C, MB, and SS compiled the manuscript.

\section{REFERENCES}

Abe, J., Alop-Mabuti, A., Burger, P., Button, J., Ellsberry, M., Hitzeman, J., et al. (2016). Comparing the temporal colonization and microbial diversity of showerhead biofilms in Hawai'i and Colorado. FEMS Microbiol. Lett. 363:fnw005. doi: 10.1093/femsle/fnw005

Babič, M. N., Zalar, P., Ženko, B., Džeroski, S., and Gunde-Cimerman, N. (2016). Yeasts and yeast-like fungi in tap water and groundwater, and their transmission to household appliances. Fungal Ecol. 20, 30-39. doi: 10.1016/j. funeco.2015.10.001

Babič, M. N., Zalar, P., Ženko, B., Schoers, H. J., Džeroski, S., and Gunde-Cimerman, N. (2015). Candida and Fusarium species known as opportunistic human pathogens from customer-accessible parts of residential washing machines. Fungal Biol. 119, 95-113. doi: 10.1016/j.funbio.2014. 10.007

Babič, N. M., Zalar, P., and Gunde-Cimerman, N. (2013). "Black yeasts enter household appliances via water," in Fifth Meeting of the ISHAM Working Groups on Black Yeasts and Chromoblastomycosis. Electronic Abstracts (Guangzhou: ISHAM). Available at: http://www.blackyeast.org/Guangzhou/ Download/Abstract.pdf

Barberán, A., Bates, S. T., Casamayor, E. O., and Fierer, N. (2012). Using network analysis to explore co-occurrence patterns in soil microbial communities. ISME J. 6, 343-351. doi: 10.1038/ismej.2011.119

Binder, S., Levitt, A. M., Sacks, J. J., and Hughes, J. M. (1999). Emerging infectious diseases: public health issues for the 21st century. Science 284, 1311-1313. doi: $10.1126 /$ science.284.5418.1311

BMSAB (2017). Bergey's Manual of Systematics of Archaea and Bacteria (BMSAB), ed. W. B. Whitman (Hoboken, NJ: John Wiley \& Sons).

Burkowska-But, A., Kalwasińska, A., and Swiontek Brzezinska, M. (2015). Bacterial growth and biofilm formation in household-stored groundwater collected from public wells. J. Water Health 13, 353-361. doi: 10.2166/wh. 2014.097

Burmølle, M., Ren, D., Bjarnsholt, T., and Sørensen, S. J. (2014). Interactions in multispecies biofilms: do they actually matter? Trends Microbiol. 22, 84-91. doi: 10.1016/j.tim.2013.12.004

Burmølle, M., Webb, J. S., Rao, D., Hansen, L. H., Sørensen, S. J., and Kjelleberg, S. (2006). Enhanced biofilm formation and increased resistance to antimicrobial agents and bacterial invasion are caused by synergistic interactions in

\section{FUNDING}

This research was funded by the Ministry of Higher Education, Science and Technology of the Republic of Slovenia, as a Young Researcher grant to JZ (grant no. 382228-1/2013). We also thank the Slovenian Research Agency (Infrastructural Centre Mycosmo, MRIC UL) and the Danish Council for Independent Research grant: 132300235 for providing financial support.

\section{ACKNOWLEDGMENTS}

Our acknowledgments go to all the people who kindly provided samples from their dishwashers. We also thank Karin Vestberg for her assistance with NGS and prof. Børge Diderichsen for careful and critical reading of the manuscript.

\section{SUPPLEMENTARY MATERIAL}

The Supplementary Material for this article can be found online at: https://www.frontiersin.org/articles/10.3389/fmicb. 2018.00021/full\#supplementary-material

multispecies biofilms. Appl. Environ. Microbiol. 72, 3916-3923. doi: 10.1128/ AEM.03022-05

Callewaert, C., Van Nevel, S., Kerckhof, F. M., Granitsiotis, M. S., and Boon, N. (2015). Bacterial exchange in household washing machines. Front. Microbiol. 6:1381. doi: 10.3389/fmicb.2015.01381

Carpentier, B., and Chassaing, D. (2004). Interactions in biofilms between Listeria monocytogenes and resident microorganisms from food industry premises. Int. J. Food Microbiol. 97, 111-122. doi: 10.1016/j.ijfoodmicro.2004.03.031

Ceri, H., Olson, M. E., Stremick, C., Read, R. R., Morck, D., and Buret, A. (1999). The calgary biofilm device: new technology for rapid determination of antibiotic susceptibilities of bacterial biofilms. J. Clin. Microbiol. 37, 1771-1776.

Chmielewski, R. A., and Frank, J. F. (2004). A predictive model for heat inactivation of Listeria monocytogenes biofilm on stainless steel. J. Food Prot. 67, 2712-2718. doi: 10.4315/0362-028X-67.12.2712

Corcoran, M., Morris, D., De Lappe, N., O’Connor, J., Lalor, P., Dockery, P., et al. (2014). Commonly used disinfectants fail to eradicate Salmonella enterica biofilms from food contact surface materials. Appl. Environ. Microbiol. 80, 1507-1514. doi: 10.1128/AEM.03109-13

Costerton, J. W., Lewandowski, Z., Caldwell, D. E., Korber, D. R., and LappinScott, H. M. (1995). Microbial biofilms. Annu. Rev. Microbiol. 49, 711-745. doi: 10.1146/annurev.mi.49.100195.003431

Davey, M. E., and O'toole, G. A. (2000). Microbial biofilms: from ecology to molecular genetics. Microbiol. Mol. Biol. Rev. 64, 847-867. doi: 10.1128/MMBR. 64.4.847-867.2000

De Almeida, G. M., Costa, S. F., Melhem, M., Motta, A. L., Szeszs, M. W., Miyashita, F., et al. (2008). Rhodotorula spp. isolated from blood cultures: clinical and microbiological aspects. Med. Mycol. 46, 547-556. doi: 10.1080/ 13693780801972490

De Brucker, K., Tan, Y., Vints, K., De Cremer, K., Braem, A., Verstraeten, N., et al. (2015). Fungal $\beta$-1,3-glucan increases ofloxacin tolerance of Escherichia coli in a polymicrobial E. coli/Candida albicans biofilm. Antimicrob. Agents Chemother. 59, 3052-3058. doi: 10.1128/AAC.04650- 14

de Hoog, G. S., Guarro, J., Figueras, M. J., and Gené, J. (2014). Atlas of Clinical Fungi: The Ultimate Benchtool for Diagnostics, 4th CD-ROM Edn. Utrecht: CBS-KNAW Fungal Biodiversity Centre.

de Souza, C. D., Faria, Y. V., Sant'Anna Lde, O., Viana, V. G., Seabra, S. H., Souza, M. C., et al. (2015). Biofilm production by multiresistant Corynebacterium 
striatum associated with nosocomial outbreak. Mem. Inst. Oswaldo Cruz 110, 242-248. doi: 10.1590/0074-02760140373

Döğen, A., Kaplan, E., Oksüz, Z., Serin, M. S., Ilkit, M., and de Hoog, G. S. (2013). Dishwashers are a major source of human opportunistic yeast-like fungi in indoor environments in Mersin, Turkey. Med. Mycol. 5, 493-498. doi: 10.3109/ 13693786.2012 .738313

Donlan, R. M. (2002). Biofilms: microbial life on surfaces. Emerg. Infect. Dis. 8, 881-890. doi: 10.3201/eid0809.020063

Eiler, A., Heinrich, F., and Bertilsson, S. (2012). Coherent dynamics and association networks among lake bacterioplankton taxa. ISME J. 6, 330-342. doi: 10.1038/ ismej.2011.113

Elias, S., and Banin, E. (2012). Multi-species biofilms: living with friendly neighbors. FEMS Microbiol. Rev. 36, 990-1004. doi: 10.1111/j.1574-6976.2012. 00325.x

Filoche, S. K., Zhu, M., and Wu, C. D. (2004). In situ biofilm formation by multispecies oral bacteria under flowing and anaerobic conditions. J. Dent. Res. 83, 802-806. doi: 10.1177/154405910408301013

Freedonia (2016). World Major Household Appliances. Available at: http://www.freedoniagroup.com/industry-study/world-major-householdappliances-3366.htm? referrerid $=$ fg-01 [accessed November 2, 2016].

Frey-Klett, P., Burlinson, P., Deveau, A., Barret, M., Tarkka, M., and Sarniguet, A. (2011). Bacterial-fungal interactions: hyphens between agricultural, clinical, environmental, and food microbiologists. Microbiol. Mol. Biol. Rev. 75, 583-609. doi: 10.1128/MMBR.00020-11

Gerrits van den Ende, A. H. G., and de Hoog, G. S. (1999). Variability and molecular diagnostics of the neurotropic species Cladophialophora bantiana. Stud. Mycol. $43,151-162$.

Ghannoum, M. (2016). Cooperative Evolutionary Strategy between the Bacteriome and Mycobiome. mBio 7:e1951-16. doi: 10.1128/mBio.01951-16

Gorny, R. L., Dutkiewicz, J., and Krysinska-Traczyk, E. (1999). Size distribution of bacterial and fungal bioaerosols in indoor air. Ann. Agric. Environ. Med. 6, 105-113.

Gümral, R., Özhak-Baysan, B., Tümgör, A., Saraçlı, M. A., Yıldıran, ŞT., Ilkit, M., et al. (2016). Dishwashers provide a selective extreme environment for humanopportunistic yeast-like fungi. Fungal Divers. 76, 1-9. doi: 10.1007/s13225-0150327-8

Hall-Stoodley, L., Costerton, J. W., and Stoodley, P. (2004). Bacterial biofilms: from the natural environment to infectious diseases. Nat. Rev. Microbiol. 2, 95-108. doi: $10.1038 /$ nrmicro821

Harriott, M. M., and Noverr, M. C. (2011). Importance of Candida-bacterial polymicrobial biofilms in disease. Trends Microbiol. 19, 557-563. doi: 10.1016/ j.tim.2011.07.004

HilleRisLambers, J., Adler, P. B., Harpole, W. S., Levine, J. M., and Mayfield, M. M. (2012). Rethinking community assembly through the lens of coexistence theory. Annu. Rev. Ecol. Evol. Syst. 43, 227-248. doi: 10.1146/annurev-ecolsys-110411160411

Hiruma, M., Kawada, A., Ohata, H., Ohnishi, Y., Takahashi, H., Yamazaki, M., et al. (1993). Systemic phaeohyphomycosis caused by Exophiala dermatitidis. Mycoses 36, 1-7. doi: 10.1111/j.1439-0507.1993.tb 00679.x

Hoarau, G., Mukherjee, P. K., Gower-Rousseau, C., Hager, C., Chandra, J., Retuerto, M. A., et al. (2016). Bacteriome and mycobiome interactions underscore microbial dysbiosis in familial Crohn's disease. mBio 7:e1250-16. doi: $10.1128 / \mathrm{mBio} .01250-16$

Iakhiaeva, E., Howard, S. T., Brown Elliott, B. A., McNulty, S., Newman, K. L., Falkinham, J. O. III, et al. (2016). Variable-number tandem-repeat analysis of respiratory and household water biofilm isolates of "Mycobacterium avium subsp. hominissuis" with establishment of a PCR database. J. Clin. Microbiol. 54, 891-901. doi: 10.1128/JCM.02409-15

Kalan, L., Loesche, M., Hodkinson, B. P., Heilmann, K., Ruthel, G., Gardner, S. E., et al. (2016). Redefining the chronic-wound microbiome: fungal communities are prevalent, dynamic, and associated with delayed healing. mBio 7:e1058-16. doi: $10.1128 / \mathrm{mBio} .01058-16$

Kittelmann, S., Seedorf, H., Walters, W. A., Clemente, J. C., Knight, R., Gordon, J. I., et al. (2013). Simultaneous amplicon sequencing to explore co-occurrence patterns of bacterial, archaeal and eukaryotic microorganisms in rumen microbial communities. PLOS ONE 8:e47879. doi: 10.1371/journal. pone.0047879
Klayman, B. J., Volden, P. A., Stewart, P. S., and Camper, A. K. (2009). Escherichia coli $\mathrm{O} 157: \mathrm{H} 7$ requires colonizing partner to adhere and persist in a capillary flow cell. Environ. Sci. Technol. 43, 2105-2111. doi: 10.1021/es802 $218 \mathrm{q}$

Kondori, N., Gilljam, M., Lindblad, A., Jönsson, B., Moore, E. R., and Wennerås, C. (2011). High rate of Exophiala dermatitidis recovery in the airways of patients with cystic fibrosis is associated with pancreatic insufficiency. J. Clin. Microbiol. 49, 1004-1009. doi: 10.1128/JCM.01899-10

Kong, E. F., Tsui, C., Kucharíková, S., Andes, D., Van Dijck, P., and Jabra-Rizk, M. A. (2016). Commensal protection of Staphylococcus aureus against antimicrobials by Candida albicans biofilm matrix. mBio 7:e1365-16. doi: $10.1128 / \mathrm{mBio} 01365-16$

Lane, D. J. (1991). “16S/23S rRNA sequencing," in Nucleic Acid Techniques in Bacterial Systematics, eds E. Stackebrandt and M. Goodfellow (Chichester: John Wiley and Sons), 115-175.

Lee, J., Cartwright, R., Grueser, T., and Pascall, M. A. (2007). Efficiency of manual dishwashing conditions on bacterial survival on eating utensils. J. Food Engineer. 80, 885-891. doi: 10.1016/j.jfoodeng.2006.08.003

Lee, K. W., Periasamy, S., Mukherjee, M., Xie, C., Kjelleberg, S., and Rice, S. A. (2014). Biofilm development and enhanced stress resistance of a model, mixedspecies community biofilm. ISME J. 8, 894-907. doi: 10.1038/ismej.2013.194

Ling, F., Hwang, C., LeChevallier, M. W., Andersen, G. L., and Liu, W. T. (2016). Core-satellite populations and seasonality of water meter biofilms in a metropolitan drinking water distribution system. ISME J. 10, 582-595. doi: $10.1038 /$ ismej.2015.136

Lister, J. L., and Horswill, A. R. (2014). Staphylococcus aureus biofilms: recent developments in biofilm dispersal. Front. Cell. Infect. Microbiol. 4:178. doi: $10.3389 /$ fcimb. 2014.00178

Lührig, K., Canbäck, B., Paul, C. J., Johansson, T., Persson, K. M., and Rådström, P. (2015). Bacterial community analysis of drinking water biofilms in southern Sweden. Microbes Environ. 30, 99-107. doi: 10.1264/jsme2.ME 14123

Lunardi, L. W., Aquino, V. R., Zimerman, R. A., and Goldani, L. Z. (2006). Epidemiology and outcome of Rhodotorula fungemia in a tertiary care hospital. Clin. Infect. Dis. 43, 60-63. doi: 10.1086/507036

Madsen, J. S., Røder, H. L., Russel, J., Sørensen, H., Burmølle, M., and Sørensen, S. J. (2016). Coexistence facilitates interspecific biofilm formation in complex microbial communities. Environ. Microbiol. 18, 2565-2574. doi: 10.1111/14622920.13335

Marouani-Gadri, N., Augier, G., and Carpentier, B. (2009). Characterization of bacterial strains isolated from a beef-processing plant following cleaning and disinfection - Influence of isolated strains on biofilm formation by Sakaï and EDL 933 E. coli O157:H7. Int. J. Food Microbiol. 133, 62-67. doi: 10.1016/j. ijfoodmicro.2009.04.028

Minerdi, D., Moretti, M., Gilardi, G., Barberio, C., Gullino, M. L., and Garibaldi, A. (2008). Bacterial ectosymbionts and virulence silencing in a Fusarium oxysporum strain. Environ. Microbiol. 10, 1725-1741. doi: 10.1111/ j.1462-2920.2008.01594.x

Moons, P., Michiels, C. W., and Aertsen, A. (2009). Bacterial interactions in biofilms. Crit. Rev. Microbiol. 35, 157-168. doi: 10.1080/10408410902809431

Morens, D. M., Folkers, G. K., and Fauci, A. S. (2004). The challenge of emerging and re-emerging infectious diseases. Nature 430, 242-249. doi: $10.1038 /$ nature 02759

Mullis, S. N., and Falkinham, J. O. III. (2013). Adherence and biofilm formation of Mycobacterium avium, Mycobacterium intracellulare and Mycobacterium abscessus to household plumbing materials. J. Appl. Microbiol. 115, 908-914. doi: $10.1111 /$ jam. 12272

Nadell, C. D., Drescher, K., and Foster, K. R. (2016). Spatial structure, cooperation and competition in biofilms. Nat. Rev. Microbiol. 14, 589-600. doi: 10.1038/ nrmicro.2016.84

Nicolella, C., Casini, B., Rossi, F., Chericoni, A., and Pardini, G. (2011). Thermal sanitizing in a commercial dishwashing machine. J. Food Saf. 31, 81-90. doi: 10.1111/j.1745-4565.2010.00270.x

O’Donnell, K., Cigelnik, E., and Nirenberg, H. (1998). Molecular systematics and phylogeography of the Gibberella fujikuroi species complex. Mycologia 90, 465-493. doi: 10.2307/3761407

Pammi, M., Liang, R., Hicks, J., Mistretta, T. A., and Versalovic, J. (2013). Biofilm extracellular DNA enhances mixed species biofilms of Staphylococcus 
epidermidis and Candida albicans. BMC Microbiol. 13:257. doi: 10.1186/14712180-13-257

Park, D. K., Bitton, G., and Melker, R. (2006). Microbial inactivation by microwave radiation in the home environment. J. Environ. Health 69, 17-24.

Pathak, A. K., Sharma, S., and Shrivastva, P. (2012). Multi-species biofilm of Candida albicans and non-Candida albicans Candida species on acrylic substrate. J. Appl. Oral Sci. 20, 70-75. doi: 10.1590/S1678-77572012000100013

Poyntner, C., Blasi, B., Arcalis, E., Mirastschijski, U., Sterflinger, K., and Tafer, H. (2016). The transcriptome of Exophiala dermatitidis during Ex-vivo skin model infection. Front. Cell. Infect. Microbiol. 6:136. doi: 10.3389/fcimb.2016.00136

Raghupathi, P. K., Zupančič, J., Brejnrod, A. D., Jacquiod, S., Houf, K., Burmølle, M., et al. (2018). Microbiomes in Dishwashers: analysis of the microbial diversity and putative opportunistic pathogens in dishwasher biofilm communities. Appl. Environ. Microbiol. doi: 10.1128/AEM.02755-17 [Epub ahead of print].

Ramage, G., Mowat, E., Jones, B., Williams, C., and Lopez-Ribot, J. (2009). Our current understanding of fungal biofilms. Crit. Rev. Microbiol. 35, 340-355. doi: 10.3109/10408410903241436

Ren, D., Madsen, J. S., Sørensen, S. J., and Burmølle, M. (2015). High prevalence of biofilm synergy among bacterial soil isolates in cocultures indicates bacterial interspecific cooperation. ISME J. 9, 81-89. doi: 10.1038/ismej.2014.96

Røder, H. L., Raghupathi, P. K., Herschend, J., Brejnrod, A., Knøchel, S., Sørensen, S. J., et al. (2015). Interspecies interactions result in enhanced biofilm formation by co-cultures of bacteria isolated from a food processing environment. Food Microbiol. 51, 18-24. doi: 10.1016/j.fm.2015.04.008

Roggenbuck, M., Schnell, I. B., Blom, N., Bælum, J., Bertelsen, M. F., SicheritzPontén, T., et al. (2014). The microbiome of new world vultures. Nat. Commun. 5:5498. doi: 10.1038/ncomms6498

Russo, J. P., Raffaeli, R., Ingratta, S. M., Rafti, P., and Mestroni, S. (2010). Cutaneous and subcutaneous phaeohyphomycosis. Skinmed 8, 366-369.

Schwering, M., Song, J., Louie, M., Turner, R. J., and Ceri, H. (2013). Multispecies biofilms defined from drinking water microorganisms provide increased protection against chlorine disinfection. Biofouling 29, 917-928. doi: 10.1080/ 08927014.2013.816298

Seneviratne, G., Zavahir, J. S., Bandara, W. M. M. S., and Weerasekara, M. L. M. A. W. (2007). Fungal-bacterial biofilms: their development for novel biotechnological applications. World J. Microbiol. Biotechnol. 24:739. doi: 10.1007/s11274-007-9539-8

Sharma, A., Inagaki, S., Sigurdson, W., and Kuramitsu, H. K. (2005). Synergy between Tannerella forsythia and Fusobacterium nucleatum in biofilm formation. Oral Microbiol. Immunol. 20, 39-42. doi: 10.1111/j.1399-302X.2004. 00175.x

Sheppard, D. C., and Howell, P. L. (2016). Biofilm exopolysaccharides of pathogenic fungi: lessons from bacteria. J. Biol. Chem. 291, 12529-12537. doi: 10.1074/jbc.R116.720995

Silva, S., Negri, M., Henriques, M., Oliveira, R., Williams, W. D., and Azeredo, J. (2012). Candida glabrata, Candida parapsilosis and Candida tropicalis: biology, epidemiology, pathogenicity and antifungal resistance. FEMS Microbiol. Rev. 36, 288-305. doi: 10.1111/j.1574-6976.2011.00278.x

Srey, S., Jahid, I. K., and Ha, S. D. (2013). Biofilm formation in food industries: a food safety concern. Food Control 31, 572-585. doi: 10.1016/j.foodcont.2012. 12.001
Ståhl Wernersson, E., Johansson, E., and Håkanson, H. (2004). Crosscontamination in dishwashers. J. Hosp. Infect. 56, 312-317. doi: 10.1016/j.jhin. 2004.01.002

Sudhadham, M., Prakitsin, S., Sivichai, S., Chaiyarat, R., Dorrestein, G. M., Menken, S. B., et al. (2008). The neurotropic black yeast Exophiala dermatitidis has a possible origin in the tropical rain forest. Stud. Mycol. 61, 145-155. doi: $10.3114 /$ sim.2008.61.15

Tolker-Nielsen, T. (2014). Pseudomonas aeruginosa biofilm infections: from molecular biofilm biology to new treatment possibilities. APMIS Suppl 138, 1-51. doi: 10.1111/apm.12335

Trofa, D., Gácser, A., and Nosanchuk, J. D. (2008). Candida parapsilosis, an emerging fungal pathogen. Clin. Microbiol. Rev. 21, 606-625. doi: 10.1128/ CMR.00013-08

Van Houdt, R., and Michiels, C. W. (2010). Biofilm formation and the food industry, a focus on the bacterial outer surface. J. Appl. Microbiol. 109, 1117-1131. doi: 10.1111/j.1365-2672.2010.04756.x

Vilanova, C., Iglesias, A., and Porcar, M. (2015). The coffee-machine bacteriome: biodiversity and colonisation of the wasted coffee tray leach. Sci. Rep. 5:17163. doi: 10.1038/srep 17163

Vishnivetskaya, T. A., Kathariou, S., and Tiedje, J. M. (2009). The Exiguobacterium genus: biodiversity and biogeography. Extremophiles 13, 541-555. doi: 10.1007/ s00792-009-0243-5

Vogel, H. J., and Bonner, D. M. (1956). Acetylornithinase of Escherichia coli: partial purification and some properties. J. Biol. Chem. 218, 97-106.

Wen, Z. T., Yates, D., Ahn, S. J., and Burne, R. A. (2010). Biofilm formation and virulence expression by Streptococcus mutans are altered when grown in dual-species model. BMC Microbiol. 10:111. doi: 10.1186/1471-218010-111

Zalar, P., Novak, M., de Hoog, G. S., and Gunde-Cimerman, N. (2011). Dishwashers - A man-made ecological niche accommodating human opportunistic fungal pathogens. Fungal Biol. 115, 997-1007. doi: 10.1016/j. funbio.2011.04.007

Zhalnina, K., de Quadros, P. D., Gano, K. A., Davis-Richardson, A., Fagen, J. R., Brown, C. T., et al. (2013). Ca. Nitrososphaera and Bradyrhizobium are inversely correlated and related to agricultural practices in long-term field experiments. Front. Microbiol. 4:104. doi: 10.3389/fmicb.2013.00104

Zupančič, J., Novak Babic, M., Zalar, P., and Gunde-Cimerman, N. (2016). The black yeast Exophiala dermatitidis and other selected opportunistic human fungal pathogens spread from dishwashers to kitchens. PLOS ONE 11:e0148166. doi: 10.1371/journal.pone.0148166

Conflict of Interest Statement: The authors declare that the research was conducted in the absence of any commercial or financial relationships that could be construed as a potential conflict of interest.

Copyright (C) 2018 Zupančič, Raghupathi, Houf, Burmølle, Sørensen and GundeCimerman. This is an open-access article distributed under the terms of the Creative Commons Attribution License (CC BY). The use, distribution or reproduction in other forums is permitted, provided the original author(s) and the copyright owner are credited and that the original publication in this journal is cited, in accordance with accepted academic practice. No use, distribution or reproduction is permitted which does not comply with these terms. 